\title{
The Impact of Work Method on Musculoskeletal Disorders Complaints in Pharmacy Unit
}

\author{
Achmad Delianur Nasution ${ }^{1}$ dan Eka Lestari Mahyuni ${ }^{2 *}$ \\ ${ }^{1}$ Directorate of Infrastructure dan Medical Support of USU Hospital, the University of \\ Sumatra Utara, Medan, Indonesia \\ ${ }^{2}$ Department of Occupational Health and Safety, Faculty of Public Health, the University of \\ Sumatra Utara, Medan, Indonesia
}

*corresponding author, e-mail: eka.lestari@usu.ac.id

Received: 30/09/2019; published: 29/09/2020

\begin{abstract}
Background: Musculoskeletal disorders (MSDs) are complaints on parts of skeletal muscle which is perceived by someone ranging from mild to severe. These complaints often occur in the manual process, heavy workload, and work environment interactions that may lead to a nonergonomic work posture. This study aims to analyze the impact of the work method to MSDs complaints at the pharmacy unit of The University of Sumatera Utara Hospital. Method: This study is an observational survey using a cross-sectional design. The population was all workers in the pharmacy unit of the University of Sumatera Utara Hospital numbered 27 people. Samples were taken from the total population. Data were collected using camera media and direct observation of the work process that took place in the pharmacy unit of USU Hospital. Musculoskeletal complaints were obtained by mapping the pain using Nordic Body Map (NBM). The data obtained were analyzed using a simple logistic regression test to see the impact of the working methods of the pharmacy unit workers on their complaints of musculoskeletal disorders. Results: There was a significant association between work methods in the Pharmacy unit and the MSDs complaints with $p$-value $=0,001$. This was supported by the mean of the work patterns in the pharmacy unit which have a heavy workload and the interaction with the layout according to anthropometry. There was a significant association between the work method causing musculoskeletal complaints when the drug compounding process $(p=0.000)$. It was evidenced from the result of NBM questionnaire that the three most prevalent complaints of MSDs were pain around the neck, back, and right shoulder. Conclusion: It can be concluded that the static working methods with a heavy workload must be accompanied by a relaxation to avoid burn out and fatigue.
\end{abstract}

Keywords: MSDs; ergonomics; pharmaceuticals; methods; work

Copyright $@ 2013$ Universitas Ahmad Dahlan. All rights reserved.

\section{Introduction}

Healthcare workers is a working group which has a high risk for musculoskeletal disorders (MSDs). Their physical work patterns which require them to stand, sit, squat, etc. are characterized as an exposure of a non-ergonomic working environment. MSDs are complaints about skeletal muscle conditions in which pain people experienced ranges from mild to severe. MSDs generally concerns with symptoms which related to muscle tissues, tendon, ligament, cartilage, nerves' system, bone structure, and blood vessels. At first, the disorder will cause pain, itchy sensation, numbness, pins and needles sensation, swelling, stiffness, shivering, sleeping disorders, and burning sensation which may affect one's movement. If the muscle becomes the subject of a repetitive static load in a long period of time, the joint, ligament, or tendon will be damaged (1-3).

MSDs conditions including swellings and degenerative conditions of muscle, tendon, ligament, back joint, shoulder, forearm, and upper extremities as well as lower 
extremities also need to be examined. As reported in various countries, MSDs affects their medical expenses and lowered their quality of life of which both are associated with occupational diseases. In the United States, Canada, Finland, Sweden, and England, MSDs causes a high rate of absenteeism $(4,5)$. In several countries, MSDs are considered as severe problems related to occupational diseases experienced by healthcare workers. MSDs are considered as chronic diseases in Norway, not to mention, they are also considered as a chronic condition of back pain in Ontario, Canada. MSDs are also considered as fatal threats and severe cases since they also occur in many other countries such as Afrika, Portugal, Uganda and are the result of either personal working characteristics or working methods and pressure (6-11).

According to WHO Global Plan of Action on Workers' Health 2008-2017 (2013), MSDs are recorded as the second most prevalent occupational disease right below respiratory disease (12,13). Based on the data from Labour Force Survey (LFS) U.K (2019), the number of MSDs among workers was very high with a total of 1.144 .000 cases, consisting of 493.000 back cases, 426.000 upper extremities or neck cases, and 224.000 lower extremities cases (14). In the U.K., the total new cases in 2018/2019 reached 498.000 of which $41 \%$ of them stroke the upper waist and neck, $40 \%$ of them stroke the back, and the other $19 \%$ of them stroke the lower waist which caused about 6.900 .000 working days lost (15). As reported by the data from the Occupational Safety and Health Administration (OSHA) in $2013,54 \%$ of injuries suffered by healthcare workers in hospitals are caused by MSDs. Moreover, the results of the research conducted by various countries have also indicated that MSDs have been one of the most prevalent occupational diseases. In the United States, it is predicted that around 6 million cases of MSDs happen each year or around the average of 300-400 cases occur per 100 thousand workers. Such problems might cause working days lost which leads to an economic loss in the company due to the decrease in productivity (16).

According to several studies, MSDs problems are potentially suffered by healthcare workers including those who work in the pharmacy unit. This problem can occur due to many factors either from work or non-work factors. Daily activities can also trigger both physical and psychological MSDs (17). Based on the work process, pharmacy unit workers are vulnerable to ergonomic hazard from computer works during drugs data collection and classification, working area design, repetitive activities, non-ergonomic pressures and postures, repetitive motions, as well as the static postures while compounding, packing, accepting, and formulating the drug as well as drug spills. Consequently, those risk factors caused the pharmacy workers to suffer from MSDs such as low back pain and neck pain. Pharmacy workers are also vulnerable to occupational accidents such as falling. Slippery surface and spilled chemical substances can also contribute to their occupational accidents aside from work processes or unnatural working postures (17-23).

The University of Sumatra Utara (USU) Hospital is one of the hospitals registered under the Director-General of Higher Education Ministry of Education and Culture and is managed by the University of Sumatra Utara. The pharmacy unit is a part of the hospital units which has a synergistic relationship with the number of patients in the hospital. Healthcare workers especially those who work in the pharmacy unit carry a quite high working load in delivering healthcare services. Their responsibilities include compounding, classifying, and dispensing the drugs based on the given prescription, as well as lifting and carrying the drugs. Consequently, they tend to adopt standing or sitting working posture for a long period of time, walking back and forth to pick and verify the drugs' qualifications which will be dispensed towards the patients according to the prescription. This study aimed to analyze the MSDs impact based on the working methods in the pharmacy unit of USU Hospital.

\section{Methods}

This study is an observational survey with a cross-sectional study design. USU Hospital was a newly operated hospital. The population in this research were all 27 healthcare workers in the pharmacy unit of the USU hospital which were also the sample of the study. This study was conducted in 2018 and was a part of the work programs carried 
out by the Occupational Health and Safety (OHS) Unit of USU Hospital. The data were collected by the help of the hospital's OHS workers through documentation using a camera and direct observation of work processes in the pharmacy unit of USU hospital. The object of the survey was the working methods employed in the pharmacy unit including the carrying process, and the drug compounding process, classification, and distribution. The MSDs complaints by the pharmacy worker were obtained by conducting pain mapping using Nordic Body Map. The categories were collected through measuring the score of the pain level perceived by the pharmacy workers and then were classified using risk level classification based on their individual scores. Individual scores were measured using a 4point Likert-Scale ranging from 1 for no pain, 2 for mild pain, 3 for pain, and 4 for severe pain. The data obtained were then analyzed using the Simple Logistic Regression test to observe the impact of pharmacy workers' working methods on their MSDs complaints.

\section{Results and discussion}

\subsection{Results}

The characteristics of the pharmacy workers in USU Hospital pharmacy shown in Table 1 indicated that most of the population were $23-28$ years old $(55,5 \%)$, predominantly are female $(96,3 \%)$, mostly works for more than 8 hours a day $(81,5)$, have been working there for $0-2$ years $(81,5 \%)$, and is in the morning shift $(82,5 \%)$. More elaborated results are presented in Table 1.

Table 1. The characteristics of pharmacy workers in USU Hospital pharmacy

\begin{tabular}{|c|c|c|}
\hline \multirow{2}{*}{ Variable } & \multicolumn{2}{|c|}{ Respondents } \\
\hline & $\mathbf{n}$ & $\%$ \\
\hline \multicolumn{3}{|l|}{ Age } \\
\hline $23-28$ years old & 15 & 55,5 \\
\hline 29-32 years old & 12 & 44,5 \\
\hline \multicolumn{3}{|l|}{ Sex } \\
\hline Female & 26 & 96,3 \\
\hline Male & 1 & 3,7 \\
\hline \multicolumn{3}{|l|}{ Work duration } \\
\hline$<8$ hours/day & 3 & 11,1 \\
\hline$\geq 8$ hours/day & 24 & 88,9 \\
\hline \multicolumn{3}{|l|}{ Years of service } \\
\hline $0-2$ years & 22 & 81.5 \\
\hline$>2-4$ years & 5 & 18.5 \\
\hline \multicolumn{3}{|l|}{ Working Shift } \\
\hline $\begin{array}{l}\text { Morning } \\
\text { Evening }\end{array}$ & 22 & 81,5 \\
\hline
\end{tabular}

The working methods were all done manually from accepting prescriptions from other units in the hospital, preparing the drugs (including drug compounding process whenever necessary), and delivering the drugs to the patients. The pharmacy workers dispensed drugs or compounded formalin in the manufacturing room (especially for Toxic and Hazardous Materials), and then the compounded drugs were delivered to the patients or were passed to the nurse of the Operating Room (OR) (formalin 5\%). While compounding the drugs, pharmacy workers wore personal protective equipment (PPE) in the form of a laboratory gown, a mask, and gloves. The working process in the administration section involved inputting data to the computer (for example, invoice), verifying the data inputted in the service section (for example, summarizing the OR package and drug return), archiving supplies and services, and organizing stationery needs and bylaws. The excessive workload from the high drug demands was parallel to the number of patients that led to the increased risk of pharmacy workers' exposure to MSDs complaints. The analysis of 
ergonomic risks of workers suffering from MSDs based on their working methods is outlined in Table 2.

Tabel 2. Working Methods in the USU Hospital Pharmacy

\section{Working Methods}

Selecting the drugs according to The risks of this method were related to workloads and the given prescription

Verifying the drugs and The drugs and prescriptions verification methods were prescription carried out in standing posture taking place after the pharmacy workers had accepted the prescriptions. The accuracy required in the midst of rush and fatigue was a crucial factor in this method as the pharmacy workers had to check the dosage carefully while the prescriptions given by the doctors were coming continuously from various hospital units.

Compounding the drugs

Distributing the drugs to wardroom or inpatient room.

Inputting the drugs and prescription data into the computer
The risk during the compounding of the drug was the sitting posture they carried out during the process. Mild accidents such as bumping another pharmacy worker were caused by the inappropriate sitting arrangement in the compounding area.

The method for drug distribution to the wardrooms or inpatient rooms was carried out by using a trolley where the drugs were dispensed, put onto together, and delivered to each room. The risk of this method was concerned with the distribution route that was considerably far.

The pharmacy unit also carried out the registration and documentation of the drugs inputted manually into the computer. The worker who was in charge of inputting the data sat in the middle of the drug collection and distribution process that made them interacted to confirm the data of the drugs entering and leaving the pharmacy. Risk in the form of stress and inconveniences might happen and caused an error in inputting the data.

Presented in Table 3, the highest means of MSDs according to the result of the Nordic Body Map Questionnaire were complaints about pain and severe pain that occurred on the upper neck $(85,2 \%)$, pain on the back $(66,7 \%)$, and on the right shoulder $(58,7 \%)$.

Tabel 3. MSDs complaints obtained from the Nordic Body Map Questionnaire

\begin{tabular}{lcccccc}
\hline \multirow{2}{*}{ Nordic Body Map } & \multicolumn{2}{c}{ Mild Pain } & \multicolumn{2}{c}{ Pain } & \multicolumn{2}{c}{ Severe Pain } \\
\cline { 2 - 7 } & $\mathbf{N}$ & $\%$ & $\mathbf{N}$ & $\%$ & $\mathbf{N}$ & $\%$ \\
\hline Pain/stiffness in the & 16 & $59,3 \%$ & 10 & $37 \%$ & 1 & $3,7 \%$ \\
upper neck & & & & & & \\
Pain in the lower neck & 4 & $14,8 \%$ & 20 & $74,1 \%$ & 3 & $11,1 \%$ \\
Pain in the left shoulder & 14 & $51,9 \%$ & 12 & $44,4 \%$ & 1 & $3,7 \%$ \\
Pain in the right shoulder & 13 & $48,1 \%$ & 13 & $48,1 \%$ & 1 & $3,7 \%$ \\
Pain in the left upper arm & 23 & $85,2 \%$ & 3 & $11,1 \%$ & 1 & $3,7 \%$ \\
Pain in the back & 9 & $33,3 \%$ & 16 & $59,3 \%$ & 2 & $7,4 \%$ \\
Pain in the right upper & 23 & $85,2 \%$ & 4 & $14,8 \%$ & 0 & $0 \%$ \\
arm & \multicolumn{7}{c}{ Pain } \\
\hline \multicolumn{1}{c}{ Nordic Body Map } & \multicolumn{7}{c}{ Mild Pain } &
\end{tabular}

The Impact of Work Method on Muskuloskeletal Disorders.....(Achmad Delianur Nasution) 


\begin{tabular}{lcccccc}
\cline { 2 - 6 } & $\mathbf{N}$ & $\mathbf{N}$ & $\mathbf{N}$ & $\mathbf{N}$ & $\%$ \\
\hline Pain in the waist & 13 & $48,1 \%$ & 12 & $44,4 \%$ & 2 & $7,4 \%$ \\
& 16 & $59,3 \%$ & 11 & $40,7 \%$ & 0 & $0 \%$ \\
Pain in the right elbow & 23 & $85,2 \%$ & 3 & $11,1 \%$ & 1 & $3,7 \%$ \\
Pain in the left forearm & 23 & $85,2 \%$ & 3 & $11,1 \%$ & 1 & $3,7 \%$ \\
Pain in the right forearm & 23 & $85,2 \%$ & 3 & $11,1 \%$ & 1 & $3,7 \%$ \\
Pain in the left wrist & 23 & $85,2 \%$ & 3 & $11,1 \%$ & 1 & $3,7 \%$ \\
Pain in the right wrist & 23 & $85,2 \%$ & 4 & $14,8 \%$ & 0 & $0 \%$ \\
Pain in the left arm & 16 & $59,3 \%$ & 9 & $33,3 \%$ & 2 & $7,4 \%$ \\
Pain in the right arm & 17 & $63 \%$ & 7 & $25,9 \%$ & 3 & $11,1 \%$ \\
Pain in the left thigh & 23 & $85,2 \%$ & 3 & $11,1 \%$ & 1 & $3,7 \%$ \\
Pain in the right thigh & 24 & $88,9 \%$ & 3 & $11,1 \%$ & 0 & $0 \%$ \\
Pain in the left knee & 22 & $81,5 \%$ & 4 & $14,8 \%$ & 1 & $3,7 \%$ \\
Pain in the right knee & 21 & $77,8 \%$ & 6 & $22,2 \%$ & 0 & $0 \%$ \\
Pain in the left calf & 15 & $55,6 \%$ & 11 & $40,7 \%$ & 1 & $3,7 \%$ \\
Pain in the right calf & 15 & $55,6 \%$ & 12 & $44,4 \%$ & 0 & $0 \%$ \\
Pain in the left ankle & 23 & $85,2 \%$ & 3 & $11,1 \%$ & 1 & $3,7 \%$ \\
Pain in the right ankle & 24 & $88,9 \%$ & 2 & $7,4 \%$ & 1 & $3,7 \%$ \\
Pain in the left leg & 17 & $63 \%$ & 8 & $29,6 \%$ & 2 & $7,4 \%$ \\
Pain in the right leg & 16 & $59,3 \%$ & 8 & $29,6 \%$ & 3 & $11,1 \%$ \\
\hline
\end{tabular}

The result of logistic regression test showed that the risk of work methods contributed 38 times towards the prevalence of MSDs complaints ( $p$-value $<0,05 ; B=-3,258 ; \exp (B)=$ 0,038 ). Ineffective work methods may increase the MSDs complaints. Moreover, nonergonomic work posture can also be a contributing factor that triggers increasing complaints.

\subsection{Discussions}

All the pharmacy workers involved were divided into two working shifts in carrying out and delivering the pharmacy service. However, sometimes some pharmacy workers took the initiative to work together based on the daily workload. Moreover, pharmacy workers frequently asked for the other workers' help to do some of their work processes when there were a lot of patients visiting the hospital. The teamwork illustrates the deeprooted social characteristics to help each other. MSDs complaints were caused by many factors including both physical and psychosocial. Pharmacy workers' workload increases as both psychological and psychosocial burden increases. Someone's occupational competence depends on the physical and psychological factors (28). Other factors contributing to their psychosocial aspect are work pace, workplace influence, the meaning of work, assurance, appreciation, role conflicts, and social support from the supervisor (29).

Work-related issues may arise in the work environment because of the increased amount of individual physical work which exceeds the normal work activities (15). The busy pharmacy service patterns can increase stress-related workload which significant towards the MSDs complaints (29) According to previous studies, high psychological demand has caused low job control and consequently, leads to the increase of MSDs as well as low back pain, shoulder pain, knee pain, etc. (30). Individual factors, physical and psychosocial stress exposure contribute to the increase of MSDs. Therefore, it is important to reduce the physical and psychosocial stress exposure in the prevention and ergonomic intervention (31). Some other risk factors related to MSDs are repetitive movement, heavy load, strength exertion, unnatural posture, and fast hand and wrist movement. Besides, MSDs risks are also prevalent in smoking habits, high Body Mass Index (BMI), high psychological burden, static work posture, and work environment exposure (24-26).

In general, trained pharmacy workers carry out working methods in which they have to comprehend and be skilled in delivering the service, both in drug compounding and medication selection based on the given prescription. The pharmacy workers' skills are influenced by the psychological factor from the job characteristics, supports, risks, and performances during the interaction in delivering the service. The possible effects resulted 
from carrying out each work are low back pain symptoms which involves an invasive procedure, the only one affecting simultaneously of almost all MSDs (32). Based on their work methods, pharmacy workers tended to suffer from MSDs complaints which are caused by their work posture and work method with the heavy and continuous workload. This risk factor causes pain or muscle ache on parts of the body that are exposed to pressure from both repetitive and continuous working activities. Various literatures point out that innovations and programs applied during the treatments only decreased the pain but never completely relieve the pain (33).

The work process in the USU Hospital pharmacy unit was carried out 24 hours a day divided into two shifts. The pharmacy workers in this unit barely had a proper rest during the break as there was a plenteous number of prescriptions entering the unit. Normally, the pharmacy workers took the initiative by themselves to take turns to rest. This case happened as the result of the healthcare service that requires them to lift things during the direct interaction with the patients always increased back pain complaints (34). The continuous working duration also took part as a factor causing pharmacy workers' MSDs complaints. Relevant studies pointed out the significant association between work duration and the prevalence of MSDs complaints (14). The duration of non-ergonomic working posture contributed to the working risk if it remained more than 10 seconds (30). Various studies have pointed out that the most prevalent MSDs complaints occurred around the back area (32). It is evidenced that MSDs complaints also frequently occur around the lower waist, and then followed by pelvis, shoulder, and wrist (9). Accordingly, it is suggested that force and repetition might be related in terms of MSDs risks. A study about damaged muscle tissue caused by musculoskeletal exhaustion showed that the damage patterns reflected the MSDs risk observed in epidemiology. The interdependency between force and repetition associates with MSDs risks. Repetition appears to result in a modest increase in low t-force risks (35). According to the literature, the pain may persist for 7 workdays until they are exposed to MSDs complaints.

However, MSDs complaints should not be taken lightly as they are mostly the result of cumulated daily work processes and interactions. MSDs cases were caused mostly by the incompatibility of the tools, human resources, and work process of which the human resource has to carry out their work in an unnatural and nonergonomic position. Hence the application of ergonomics can be considered as an effort to reduce the MSDs (36). MSDs can persist for a long time (from weeks, months even years) and are often detected only when it reached a chronic stage when they may not be able to heal completely (37). The working position cannot be separated from the working posture adopted as pharmacy workers make direct contact with the tools and equipment. Generally, the work risks and non-ergonomic work posture adopted by pharmacy workers are resulted from the drug storage which layout is difficult to reach. To reach where the drugs are stored, pharmacy workers have to use equipment e.g. ladder or chair. Interaction with the workplace tends to give more negative influence compared to the reported musculoskeletal cases. A lengthy period of standing work posture, sitting work posture, bending work posture, or lifting heavy loads contributes to MSDs. Static stretching and improving work posture can lower the risk of Musculoskeletal pain (38).

The impact of work methods in the Pharmacy unit on the MSDs complaints showed that there was a significant association between work methods in the Pharmacy unit and the MSDs complaints with $p$-value $=0,001$. It is supported by the working pattern in the pharmacy unit which mostly is characterized by heavy workload and interaction with a layout that doesn't correspond to Anthropometry. Work method which showed a very significant relationship with MSDs complaints was the compounding drug process. It is evidenced from NBM questionnaire result where the three highest MSDs complaints are pain around the neck, back, and right shoulder. Correspondingly, the pain commonly perceived by the healthcare workers in hospitals comprising pain on the lower back and neck, thus, MSDs can hinder their work (6). The pain indicated the posture adapted from a long duration of hanging head posture and using the right hand in carrying out the drug collecting and compounding process. The pain the pharmacy workers commonly experienced including the pain on their lower back, shoulder, and neck (27). Another study 
using a logistic regression test showed that ergonomic factors including work methods had a strong association with MSDs symptoms experienced by healthcare workers. In like manner, there was a significant association between non-ergonomic position and back pain. Excessive muscle work done by pharmacy workers related to the use of needle and other hand-related work combined with long working period/duration, thumb press force, high muscle work, and lack of rest causes MSDs to happen (39-41).

Different MSDs complaints experienced by the pharmacy workers should be treated. Therefore, health promotion related to the pharmacy workload, especially for the intern who helps the pharmacy workers, is essential to reduce the pharmacy workload. MSDs complaints that strike the spine can be eased through manual therapy and spinal stabilization. The comprehensive interrelationship among various disciplines can be applied collectively to improve the physical factors related to work which causes and controls the occurrence of MSDs (42). Furthermore, education and prevention efforts are required to decrease the number of MSDs complaints (43). The use of lumbosacral support can decrease the possibility of low back pain among healthcare workers (44). Physical exercise in the workplace is more effective than home-based physical exercise in reducing Musculoskeletal pain and increasing muscle strength among healthcare workers (45).

\section{Conclusions}

Based on the results and discussions of the study, it can be concluded that the work method in the pharmacy unit affects the MSDs complaints caused by work methods that are related to the workload of the pharmacy workers and the layout of the drug storage room. Furthermore, according to the result of the test, it is suggested that a static work method with a heavy workload should be balanced with sufficient relaxation to avoid burn out and fatigue.

\section{References}

1. Gilang Permata E, Husni A. Analisis Gangguan Muskuloskeletal Terhadap Perawat Berdasarkan Tingkat Paparan dengan Menggunakan Metode Movement and Assistance of Hospital Patients (mapo) Index (Studi kasus: RSUD Arifin Achmad Provinsi Riau). J Tek Ind. 2016;2(1):54-61.

2. Humantech Inc. Applied Ergonomics Training Manual. Berkeley Vale Australia: Protector and Gamble Inc; 2002.

3. Wang J, Cui Y, He L, Xu X, Yuan Z, Jin X, et al. Work-related musculoskeletal disorders and risk factors among Chinese medical worker of obstetrics and gynecology. Int $J$ Environ Res Public Health. 2017;14(6):1-13.

4. Stock S, Baril R, Dion-Hubert C, Lapointe C, Paquette S, Sauvage J, et al. Work-related Musculoskeletal Disorders Guide and Tools for Modified Work. Montréal: santé publique; 2005. 1-63 p.

5. Hossain MD, Aftab A, Al Imam MH, Mahmud I, Chowdhury IA, Kabir RI, et al. Prevalence of work related musculoskeletal disorders (WMSDs) and ergonomic risk assessment among readymade garment workers of Bangladesh: A cross sectional study. PLoS One. 2018;13(7):1-18.

6. Luan HD, Hai NT, Xanh PT, Giang HT, Van Thuc P, Hong NM, et al. Musculoskeletal Disorders: Prevalence and Associated Factors among District Hospital Nurses in Haiphong, Vietnam. Biomed Res Int. 2018;2018:1-9.

7. Kim SS, Okechukwu CA, Dennerlein JT, Boden LI, Hopcia K, Hashimoto DM, et al. Association between perceived inadequate workering and musculoskeletal pain among hospital patient care workers. Int Arch Occup Environ Health. 2014;87(3):323-30.

8. Kinge JM, Knudsen AK, Skirbekk V, Vollset SE. Musculoskeletal disorders in Norway: Prevalence of chronicity and use of primary and specialist health care services. BMC Musculoskelet Disord. 2015;16(1):1-9.

9. Ribeiro T, Serranheira F, Loureiro H. Work Related Musculoskeletal Disorders in Primary Health Care Nurses. Appl Nurs Res. 2017;33:72-7.

10. Blanchette MA, Rivard M, Dionne CE, Hogg-Johnson S, Steenstra I. Workers' characteristics associated with the type of healthcare provider first seen for occupational 
back pain. BMC Musculoskelet Disord. 2016;17(1):1-15.

11. Munabi IG, Buwembo W, Kitara DL, Ochieng J, Mwaka ES. Musculoskeletal disorder risk factors among nursing workers in low resource settings: A cross-sectional study in Uganda. BMC Nurs. 2014;13(1):1-8.

12. World Health Organization. WHO Global Plan of Action on Workers' Health (2008-2017): Baseline for Implementation. World Health Organization. 2013.

13. Tubagus AP, Doda DVD, Wungouw HIS. Hubungan Tingkat Risiko Musculoskeletal Disorders (MSDs) Mengguna-kan Rapid Entire Body Assessment (REBA) dengan Keluhan MSDs pada Residen IImu Bedah. J Biomedik. 2018;10(3):168-73.

14. Labour Force Survey (LFS). LFS - Labour Force Survey - Self-reported work-related ill health and workplace injuries: Index of LFS tables [Internet]. United Kingdom; 2019.

15. Health and Safety Executive. Work related musculoskeletal disorder statistics (WRMSDs) in Great Britain, 2019. Health and Safety Executive. United Kingdom: Health and Safety Executive; 2019.

16. OSHA. Caring for our caregivers: Facts about Hospital Worker Safety. 2013.

17. Tribble AG, Summers P, Chen H, Quandt SA, Arcury TA. Musculoskeletal Pain, Depression, and Stress among Latino Manual Laborers in North Carolina. Arch Environ Occup Heal. 2016;71(6):309-16.

18. OSHA. Ergonomics: Guidelines for Nursing Homes: Ergonomics for the Prevention of Musculoskeletal Disorders. Occupational Safety and Health Administration. Washington, DC, USA: OSHA; 2009.

19. Labbafinejad Y, Imanizade Z, Danesh H. Ergonomic Risk Factors and Their Association with Lower Back and Neck Pain among Pharmaceutical Workers in Iran. Work Heal Saf. 2016;64(12):586-95.

20. Syahidah HN, Musfiroh I. Review: Aspek Keamanan dan Keselamatan Kerja dalam Produksi Sediaan Farmasi. Farmaka. 2018;16(1):13-20.

21. OSHA. Hospital e-Tools: Pharmacy Ergonomics [Internet]. Occupational Safety and Health Administration. [cited 2020 May 2]. Available from: https://www.osha.gov/SLTC/etools/hospital/pharmacy/pharmacy.html\#Ergonomics]

22. Nurfitria RS, Sutrisno E, Ramadhania $S$. The potency of musculoskeletal disorders ergonomic risks of pharmacy worker at a hospital pharmacy installation in Bandung. Asian $J$ Pharm Clin Res. 2018;11(13):181-6.

23. Istighfaniar K, Mulyono M. Evaluasi Postur Kerja Dan Keluhan Muskoloskeletal Pada Pekerja Instalasi Farmasi. Indones J Occup Saf Heal. 2017;5(1):81.

24. Baadjou VAE, Roussel NA, Verbunt JAMCF, Smeets RJEM, de Bie RA. Systematic review: Risk factors for musculoskeletal disorders in musicians. Occup Med (Chic III). 2016;66(8):614-22.

25. Madadizadeh F, Vali L, Rafiei S, Akbarnejad Z. Risk factors associated with musculoskeletal disorders of the neck and shoulder in the personnel of Kerman University of Medical Sciences. Electron physician. 2017;9(5):4341-8.

26. Carrillo-Castrillo JA, Pérez-Mira V, Del Carmen Pardo-Ferreira M, Rubio-Romero JC. Analysis of required investigations of work-related musculoskeletal disorders in Spain. Int $J$ Environ Res Public Health. 2019;16(10):1-14.

27. Tsekoura M, Koufogianni A, Billis E, Elias. T. Work - Related Musculoskeletal Disorders Among Female And Male Nursing Personnel In Greece. World J Res Rev. 2017;3(1):8-15.

28. Akodu AK, Ashalejo ZO. Work-related musculoskeletal disorders and work ability among hospital nurses. J Taibah Univ Med Sci. 2019;14(3):252-61.

29. Chanchai W, Songkham W, Ketsomporn P, Sappakitchanchai P, Siriwong W, Robson MG. The impact of an ergonomics intervention on psychosocial factors and musculoskeletal symptoms among Thai hospital orderlies. Int J Environ Res Public Health. 2016;13(5):1-10.

30. Bernal D, Campos-Serna J, Tobias A, Vargas-Prada S, Benavides FG, Serra C. Workrelated psychosocial risk factors and musculoskeletal disorders in hospital nurses and nursing aides: A systematic review and meta-analysis. Int J Nurs Stud. 2015;52(2):635-48.

31. Harris-Adamson C, Bao SS, Evanoff B. Musculoskeletal disorders. In: Occupational and Environmental Health. Oxford, United Kingdom: Oxford University Press; 2017. p. 433-60.

32. Serranheira F, Sousa-Uva M, Sousa-Uva A. Hospital nurses tasks and work-related 
musculoskeletal disorders symptoms: A detailed analysis. Work. 2015;51(3):401-9.

33. Alhasan M, Abdelrahman M, Alewaidat H, Almhdawi K, Nazzal M. Work-related stress, musculoskeletal disorder complaints, and stress symptoms among radiographers in the northern part of Jordan. J Med Imaging Radiat Sci. 2014;45(3):291-8.

34. Carneiro P, Martins J, Torres M. Musculoskeletal disorder risk assessment in home care nurses. Work. 2015;51(4):657-65.

35. Nuryaningtyas B., Martiana T. Analisis Tingkat Risiko Muskuloskeletal Disorders (MSDs) Dengan The Rapid Upper LIMBS Assessment (RULA) Dan Karakteristik Individu Terhadap Keluhan MSDs. Indones J Occup Saf Heal. 2014;3(2):160-9.

36. Mayasari D, Saftarina F. Ergonomi Sebagai Upaya Pencegahan Musculoskletal Disorders. $J$ Kedokt Univ Lampung. 2016;1(2):369-79.

37. Fausiyah K. Hubungan Karakteristik Individu dan IkImi Kejra dengan Keluhan MSDs pada Pekerja Perakitan Mini Bus di PT. Mekar Armada Jaya Magelang. Indones J Occup Saf Heal. 2017;6(1):48.

38. Wuriani, Rosa ME, Afandi M. Pengaruh Perbaikan Postur Kerja terhadap Nyeri Muskuloskeletal pada Perawat di Klinik Kitamura Pontianak The Influence of Work Posture Improvement to Musculoskeletal Pain Kitamura Clinic Pontianak Nurses. Mutiara Med. 2017;17(1):22-8.

39. Chaléat-Valayer E, Denis A, Abelin-Genevois K, Zelmar A, Siani-Trebern F, Touzet S, et al. Long-term effectiveness of an educational and physical intervention for preventing low-back pain recurrence: A randomized controlled trial. Scand $J$ Work Environ Heal. 2016;42(6):510-9.

40. Nourollahi M, Afshari D, Dianat I. Awkward trunk postures and their relationship with low back pain in hospital nurses. Work. 2018;59(3):317-23.

41. MacDonald V, Keir PJ. Assessment of Musculoskeletal Disorder Risk with Hand and Syringe use in Chemotherapy Nurses and Pharmacy Assistants. IISE Trans Occup Ergon Hum Factors. 2018;6(3-4):128-42.

42. Chiasson M eve, Imbeau D, Major J, Aubry K, Delisle A. Influence of musculoskeletal pain on workers' ergonomic risk-factor assessments. Appl Ergon. 2015;49:1-7.

43. Rahman M, Chowdhury A, Zaman MS, Sultana N, Amin MB, Hossain MM. Work-related musculoskeletal disorders among health care workers. Updat Dent Coll J. 2017;7(1):4-9.

44. Hagiwara $Y$, Yabe $Y$, Yamada $H$, Watanabe $T$, Kanazawa $K$, Koide M, et al. Effects of $A$ Wearable Type Lumbosacral Support for Low Back Pain among Hospital Workers: A Randomized Controlled Trial. J Occup Health. 2017;59(2):201-9.

45. Jakobsen MD, Sundstrup E, Brandt M, Jay K, Aagaard P, Andersen LL. Effect of workplaceversus home-based physical exercise on musculoskeletal pain among healthcare workers: A cluster randomized controlled trial. Scand J Work Environ Heal. 2015;41(2):153-63. 